\section{Quality of life among the Brazilian adult population using the generic SF-8 questionnaire}

\author{
Qualidade de vida da população adulta brasileira \\ através do questionário SF-8
}

\section{Abstract}

The objective of this study was to assess the quality of life in the Brazilian adult population, based on the U.S. standard population. It involved a crosssectional population-based study with probabilistic sampling of 2,420 individuals (725 men and 1695 women) aged 40 or more in different geographic regions of Brazil. A socio-demographic questionnaire and the SF-8 (Short Form-8) were administered in interview form. Descriptive statistics, analysis of variance, the Mann-Whitney test and Tukey's test were used in the analysis. Females, populations in the northeastern region, the population of the regions of Brasilia (Distrito Federal), Campo Grande (Mato Grosso do Sul State) and Goiania (Goiás State), Brazil, demonstrated worse quality of life. Age, education and income had influence over quality of life domains. This study presents quality of life estimates for the Brazilian adult population, based on the SF-8 questionnaire. The mean values on the subscales and components of the SF-8 appeared to be influenced by gender, geographic region, family income, age and schooling.

Quality of Life; Socioeconomic Survey; Demography; Health Status
Alessandro Gonçalves Campolina 1

Marcelo M. Pinheiro 1

Rozana Mesquita Ciconelli 1

Marcos Bosi Ferraz 1

\section{Introduction}

In recent decades, research into quality of life has become an emerging phenomenon in the medical literature. A large part of the current interest in this field of investigation may be attributed to concerns regarding environmental degradation and human wellbeing as well as the increasing impact of chronic disease on the health of populations $1,2,3,4$. The quest for a greater understanding of the processes involved in quality of life is aimed at broadening the perspectives of social equality as well as ecological and cultural diversity to allow a reassessment of the urban lifestyle and quality of consumption, work, distribution of wealth and access to goods and services 5 .

In this context, Health-Related Quality of Life (HRQL) has been proposed as those aspects of self-perceived well-being that are related to or affected by the presence of disease or treatment 4 . An array of scores representing individual dimensions or domains of HRQL can be provided by health profiles (or health status questionnaires). The rationale is that since such questionnaires focus on those aspects of existence that are affected by ill health, they may give some indication of the impact of illness on quality of life 6,7. The Short Form-36 (SF-36) is a well known example of such health profiles. In contrast to condition specific measures, which may be criticized for their narrowness, health profiles attempt to capture aspects of health that are important 
to all patients. They are useful for health status comparison both among patients with the same condition and between patients with different conditions. Such measures can also be administered to the general population to see how a particular condition causes health to depart from a "health standard" 8. A large number of quality of life assessment tools have been produced and validated in different countries 4 .

Among these questionnaires for measuring quality of life, the Short Form-8 (SF-8) is an advancement toward achieving the ideal combination of scope and brevity 9 . The aim of the development of this instrument was to offer an assessment tool that could be administered in one to two minutes and accurately reproduce the physical and mental results of the eight subscales in the widely used SF-36 10 . The ease and quickness of administration are the most attractive aspects of this new tool, which can be either self-administered or administered in interview form. The results are comparable to those of the SF-36 when administered to large samples, with differences in terms of precision, as the SF-8 is capable of distinguishing a lower number of health levels 9 .

The SF-36 has been translated and validated for use on the Brazilian population and is increasingly used in clinical studies 11,12,13,14. As the SF-8 was drafted in a similar manner to the SF-36, the results of the two assessment tools can be compared and interpreted using the same interpretation guidelines 9,10 .

The lack of population-based studies in Brazil hinders the comparison of investigations carried out in the country with estimates on quality of life parameters for the population. Moreover, there are no data on the geographic and socioeconomic distribution of quality of life among the Brazilian adult population, using the SF- 8 or the SF-36 instrument.

\section{Objectives}

The aim of the present study was to assess the quality of life of the Brazilian adult population (aged 40 years or more), using the generic SF-8 quality of life questionnaire.

\section{Methods}

\section{Population and sampling}

According to the last official census, Brazil has 5,507 municipalities, covering 8,514,215.3km² over 27 Federative Units. By the time the present study was carried out, the Brazilian population totaled approximately 169,799,170 inhabitants, most of which have a mixed ethnic background. Officially, the population is made up of whites (53.95\%), mulattos (38.92\%), blacks (6.2\%), Asians (6.19\%), indigenous peoples $(0.43 \%)$ and undeclared peoples $(0.66 \%)$. The majority of the population (81.2\%) lives in urban areas.

For the present study, the sample size was calculated by probabilistic sampling to represent the urban and rural populations as reported in the 2000 Brazilian National Census (Brazilian Institute of Geography and Statistics - http:/ / www. ibge.gov.br) and the 2003 National Household Sample Survey (PNAD 2003).

The sample was selected in three phases, with control of gender, age and occupation; homes were randomly selected. Interviews were performed on weekdays and weekends both day and night in order to maximize the possibility of encountering the target population at home. Sample distribution according to social class, education, marital status, ethnic group and geographic region reflected official data for the Brazilian population. The data were further weighted to respect the distribution and proportionality of the overall Brazilian population. The sampling error was estimated as $2.2 \%$ for a $95 \%$ confidence interval (95\%CI).

From March to April 2006, a total of 2,420 individuals (725 men and 1695 women) aged 40 or above, representative of all socioeconomic classes in 150 cities (less than 20,000 inhabitants; between 20 and 100,000 inhabitants; and more than 100,000 inhabitants) of the five regions of Brazil, were assessed in a cross-sectional populationbased survey. The participants pertained to different socioeconomic classes, had different degrees of schooling and held different occupations. Individuals with cognitive impairment that could compromise the consistency of the responses on the questionnaire (those with neurological diseases or dementia) were excluded from the study. If a household with more than two individuals over 40 years of age were selected, which is not uncommon in Brazil, many more individuals with very similar characteristics (diet, genetics, etc.) would be included. In order to avoid selection bias, if this happened, these households were automatically randomized again.

\section{Measurement}

Face-to-face interviews were performed by a team of trained professionals at the homes of the interviewees. Socio-demographic data (age, gender, schooling, household income and geographic region) were gathered by means of a structured 
questionnaire. Household income was calculated in the Brazilian currency (Real).

The SF-8 has three different versions: a standard version with a one-month response time (used in the present study), a version with a oneweek response time and a version with a 24 -hour response time. The questionnaire is structured with eight items, none of which is identical to those on the SF-36, but there are many similarities. It is divided into eight subscales (physical functioning, role physical, bodily pain, general health, vitality, social functioning, role emotional and mental health) and two summary components (physical and mental) through which the results are expressed.

The scores on the subscales and summary components are presented in the form of variations in relation to the population of the United States of America (mean score $=50$, standard deviation - SD = 10), where the instrument was validated. Thus, scores below 50 points correspond to deviations from normality and indicate a poorer quality of life, whereas scores above 50 points represent a better quality of life than that of the average adult American population.

As the present study is part of the Brazilian Osteoporosis Study (BRAZOS) 15, the aim of which is to determine the prevalence of risk factors for osteoporotic fractures in the Brazilian population, a greater number of women were included due to the fact that women are more frequently affected by osteoporosis. So, this is a possible analysis, considering the characteristics of the sampled population.

The mean administration time of the entire BRAZOS questionnaire was 60 minutes for each individual. Approximately $25 \%$ of the questionnaires were verified in loco or through telephone contact. All questionnaires were reviewed by an independent supervisor and were submitted to continual critiquing. Inconsistently filled out questionnaires were sent back for corrections. All participants signed terms of informed consent, which received approval from the Ethics Committee of the Universidade Federal de São Paulo.

\section{Statistical analysis}

The data are expressed as mean and SD, with $95 \%$ CI. The distribution of variables was assessed using Kolmogorov-Smirnov's test. Analysis of variance (ANOVA), the Mann-Whitney test and Tukey's test were used for the comparisons of means on the subscales and components of the SF-8 according to gender, age group, schooling, geographic area and household income. The SPSS for Windows, version 12 (SPSS Inc., Chicago, USA) and Statistical Analysis System for Win- dows, version 8.02 (SAS Inst., Cary, USA), programs were used, with the level of significance set at $5 \%(\mathrm{p}<0.05)$.

\section{Results}

The mean value on the SF-8 for the Brazilian population was generally lower than that of the American population (Table 1). The role social, the bodily pain and the mental health subscales achieved scores above 50 points, in men. Women exhibited poorer quality of life on all subscales than men, with the exception of Vitality (Table 1). Women also scored lower on the physical and mental summary components $(\mathrm{p}<0.001$ - MannWhitney test).

For most of the subscales and components, the different geographic regions of Brazil exhibited poorer quality of life than the mean of the American population. Only some of the regions exhibited a better quality of life than the mean score of the American population: Central WestInterior, Northeast-Metropolitan and SouthInterior (Table 2), however, these estimates may not be true since the confidence interval includes values below 50.00. With regard to the physical summary component, Northeast-Interior had the worst quality of life scores $(\mathrm{p}<0.05$, with the exception of the Northeast-Metropolitan Tukey's test). For the mental summary component, Brasília (Distrito Federal)/Campo Grande (Mato Grosso do Sul State)/Goiânia (Goiás State) had the worst quality of life scores $(\mathrm{p}<0.05$ for all regions - Tukey's test).

Table 3 shows a progressive reduction in quality of life with the advance in age on the different subscales of the SF-8 $(\mathrm{p}<0.01)$. ANOVA revealed no significant differences between age groups on the mental health subscale $(\mathrm{p}=0.424)$. Table 4 shows an increase in quality of life with a greater number of years of schooling on most of the subscales $(\mathrm{p}<0.01)$. Mental health was the only subscale that was not significantly influenced by schooling ( $\mathrm{p}=0.388$ - ANOVA). Table 5 shows that household income had a significant influence over quality of life on all subscales $(\mathrm{p}<$ 0.05). Individuals with lower incomes achieved worse quality of life scores on the physical summary component (ANOVA).

\section{Discussion}

The use of quality of life measures for the description of the health of a population makes it possible to identify the most compromised dimensions of wellbeing and to establish priority 
Mean values on subscales and summary components of the Short Form-8 according to gender. Brazil, 2007.

\begin{tabular}{|c|c|c|c|c|}
\hline & $\mathrm{n}$ & Mean & SD & $95 \% \mathrm{Cl}$ \\
\hline \multicolumn{5}{|c|}{ General health } \\
\hline Male & 725 & 45.36 & 8.14 & $44.77-45.96$ \\
\hline Female & 1,695 & 42.82 & 7.76 & $42.45-43.19$ \\
\hline \multicolumn{5}{|c|}{ Physical functioning } \\
\hline Male & 725 & 49.24 & 8.29 & $48.64-49.85$ \\
\hline Female & 1,695 & 46.58 & 9.15 & $46.15-47.02$ \\
\hline \multicolumn{5}{|c|}{ Role physical } \\
\hline Male & 725 & 49.09 & 8.40 & $48.48-49.71$ \\
\hline Female & 1,695 & 45.96 & 9.70 & $45.50-46.42$ \\
\hline \multicolumn{5}{|l|}{ Bodily pain } \\
\hline Male & 725 & 52.16 & 10.16 & $51.42-52.91$ \\
\hline Female & 1,695 & 47.14 & 11.35 & $46.60-47.68$ \\
\hline \multicolumn{5}{|l|}{ Vitality } \\
\hline Male & 725 & 43.01 & 10.79 & $42.22-43.80$ \\
\hline Female & 1,695 & 44.86 & 10.00 & $44.39-45.34$ \\
\hline \multicolumn{5}{|l|}{ Role social } \\
\hline Male & 725 & 52.04 & 6.87 & $51.54-52.54$ \\
\hline Female & 1,695 & 49.32 & 8.82 & $48.90-49.74$ \\
\hline \multicolumn{5}{|c|}{ Mental health } \\
\hline Male & 725 & 52.40 & 7.49 & $51.85-52.94$ \\
\hline Female & 1,695 & 48.71 & 9.75 & $48.25-49.18$ \\
\hline \multicolumn{5}{|c|}{ Role emotional } \\
\hline Male & 722 & 49.62 & 6.39 & $49.15-50.09$ \\
\hline Female & 1,683 & 47.39 & 7.87 & $47.01-47.76$ \\
\hline \multicolumn{5}{|c|}{ Physical summary component } \\
\hline Male & 725 & 48.22 & 8.94 & $47.56-48.87$ \\
\hline Female & 1,695 & 44.79 & 9.87 & $44.32-45.26$ \\
\hline \multicolumn{5}{|c|}{ Mental summary component } \\
\hline Male & 725 & 50.96 & 7.10 & $50.44-51.48$ \\
\hline Female & 1,695 & 48.39 & 9.01 & $47.96-48.82$ \\
\hline
\end{tabular}

SD: standard deviation; $95 \% \mathrm{Cl}$ : 95\% confidence interval.

areas for investments and more specific studies 4. Measures that offer normalized scores, such as the SF-8, also enable a direct comparison of the results to a reference population, allowing losses in quality of life to be interpreted in terms of deviations from normality ${ }^{9}$. Scores can be understood as departures from expected or typical scores. So, norm-based interpretation answers the questions of whether or not an observed score is typical: Is the score expected for this individual or group of individuals? In the present study, the assessment of the quality of life among the Brazilian population can be directly compared to that of the population of the United States, where the SF- 8 was validated. For example, in Table 1 an average of 45.36 for the General Health subscale in males (an atypical score), indicates that in the Brazilian population, men are at 0.54 standard deviations below the mean of the reference population (mean score $=50, \mathrm{SD}=10$ ).

The subscales and components of the measure generally reveal a lower quality of life among Brazilians. The role social subscale was an exception, on which the Brazilian population achieved a score of more than 50 points, which is above the mean of the population of the United States. The lesser sensitivity of the scale with regard to social aspects may be related to this finding 10 . In this sense, the values could be overestimated, since in Brazil these are expected to be more strongly influenced by social factors, than in the U.S. population. The subscales Bodily Pain 
Mean values on physical and mental components of the Short Form-8 according to geographic region. Brazil, 2007.

\begin{tabular}{lllll}
\hline & $\mathbf{n}$ & Mean & SD & 95\%Cl \\
\hline Physical summary component & & & & \\
Brasília/Campo Grande/Goiânia & 200 & 46.18 & 0.66 & $44.88-47.47$ \\
Central-west interior & 192 & 45.78 & 0.73 & $44.33-47.22$ \\
Northeast interior & 280 & 45.71 & 0.58 & $44.58-46.85$ \\
Northeast metropolitan region & 220 & 47.44 & 0.60 & $46.26-48.61$ \\
North interior & 200 & 43.21 & 0.69 & $41.84-44.58$ \\
North metropolitan region & 104 & 44.53 & 0.96 & $42.62-46.43$ \\
Southeast interior & 376 & 45.94 & 0.52 & $44.92-46.96$ \\
Southeast metropolitan region & 436 & 45.11 & 0.48 & $44.17-46.05$ \\
South interior & 200 & 46.49 & 0.64 & $45.22-47.75$ \\
South metropolitan region & 212 & 47.67 & 0.64 & $46.40-48.94$ \\
Mental summary component & & & & \\
Brasília/Campo Grande/Goiânia & 200 & 47.23 & 0.57 & $46.12-48.35$ \\
Central-west interior & 192 & 50.54 & 0.56 & $49.44-51.63$ \\
Northeast interior & 280 & 49.94 & 0.56 & $48.84-51.04$ \\
Northeast metropolitan region & 220 & 48.14 & 0.58 & $46.99-49.29$ \\
North interior & 200 & 49.29 & 0.60 & $48.11-50.46$ \\
North metropolitan region & 104 & 50.54 & 0.84 & $48.87-52.22$ \\
Southeast interior & 376 & 48.91 & 0.44 & $48.04-49.79$ \\
Southeast metropolitan region & 436 & 48.49 & 0.42 & $47.66-49.32$ \\
South interior & 200 & 50.50 & 0.56 & $49.39-51.62$ \\
South metropolitan region & 212 & 49.49 & 0.57 & $48.37-50.61$ \\
\hline SD: & & & &
\end{tabular}

SD: standard deviation; $95 \% \mathrm{Cl}$ : 95\% confidence interval.

and Mental Health also showed scores above 50 points, in this case the poor distribution of wealth and social inequalities may have influenced this result $10,16,17,18$. Some studies have shown that low socio-economic development can lead to a lower expectation in relation to health, causing individuals to assess their quality of life with values higher than expected. This effect has been noted mainly in males, in which different values assigned to the body, the pressing need of work, can be observed 19,20,21,22. Thus, the observed values may be overestimated in relation to the U.S. population, where the best socio-economic status cannot exert the same influence as in the case of Brazil.

The female gender had worse quality of life scores than males. The scientific literature has demonstrated that, although women have a longer life expectancy, they have shorter periods than males in which they are free of disabilities, which suggests a gender difference in terms of compromised quality of life. The factors commonly addressed to explain the poorer quality of life among women are related to gender dif- ferences in social opportunities and higher mortality rates among men at younger ages 23,24,25. Different distributions of chronic diseases and functional capacity by gender, may also influence these differences between men and women. In a population-based study conducted in Brazil, to evaluate the quality of life of seniors through the SF-36, women were in a worse situation than men in all SF-36 scales. According to the authors, the fact that women exhibit a worse self-assessed level of health may be attributed to the greater perception and knowledge that they have regarding diseases and symptoms, considering the role as a family health caregiver, that makes women dedicate more attention to the signs of diseases 20 .

The assessment of quality of life in the different geographic regions of Brazil reveals that the northeastern region scored lowest with regard to the physical component, whereas the Brasília/ Goiânia/Campo Grande region scored lowest on the mental component. The analyses of the present study do not allow an investigation into the regional factors involved in the findings on 
Mean values on subscales of the Short Form-8 according to age group. Brazil, 2007.

\begin{tabular}{|c|c|c|c|c|}
\hline & $\mathrm{n}$ & Mean & SD & $95 \% \mathrm{Cl}$ \\
\hline \multicolumn{5}{|c|}{ General health (years) } \\
\hline $40-50$ & 824 & 45.54 & 8.19 & $44.98-46.10$ \\
\hline $51-60$ & 480 & 43.86 & 7.90 & $43.15-44.57$ \\
\hline $61-70$ & 452 & 42.58 & 7.46 & $41.89-43.27$ \\
\hline 71 or more & 664 & 41.63 & 7.45 & $41.06-42.20$ \\
\hline \multicolumn{5}{|c|}{ Physical functioning (years) } \\
\hline $40-50$ & 824 & 49.05 & 8.07 & $48.50-49.60$ \\
\hline $51-60$ & 480 & 48.29 & 8.24 & $47.56-49.03$ \\
\hline $61-70$ & 452 & 46.57 & 8.86 & $45.75-47.39$ \\
\hline 71 or more & 664 & 45.20 & 10.08 & $44.43-45.97$ \\
\hline \multicolumn{5}{|c|}{ Role physical (years) } \\
\hline $40-50$ & 824 & 49.02 & 8.15 & $48.47-49.58$ \\
\hline $51-60$ & 480 & 47.51 & 9.22 & $46.68-48.34$ \\
\hline $61-70$ & 452 & 46.06 & 9.51 & $45.18-46.93$ \\
\hline 71 or more & 664 & 44.39 & 10.35 & $43.60-45.18$ \\
\hline \multicolumn{5}{|c|}{ Bodily pain (years) } \\
\hline $40-50$ & 824 & 50.34 & 11.08 & $49.58-51.10$ \\
\hline $51-60$ & 480 & 49.02 & 11.29 & $48.01-50.03$ \\
\hline $61-70$ & 452 & 47.21 & 10.86 & $46.21-48.22$ \\
\hline 71 or more & 664 & 47.25 & 11.37 & $46.39-48.12$ \\
\hline \multicolumn{5}{|l|}{ Vitality (years) } \\
\hline $40-50$ & 824 & 47.22 & 9.70 & $46.48-47.96$ \\
\hline $51-60$ & 480 & 45.19 & 9.58 & $44.30-46.07$ \\
\hline $61-70$ & 452 & 43.32 & 10.33 & $42.40-44.25$ \\
\hline 71 or more & 664 & 42.95 & 10.46 & $41.34-42.77$ \\
\hline \multicolumn{5}{|c|}{ Role social (years) } \\
\hline $40-50$ & 824 & 50.95 & 7.93 & $50.41-51.49$ \\
\hline $51-60$ & 480 & 50.58 & 7.88 & $49.87-51.29$ \\
\hline $61-70$ & 452 & 49.94 & 8.30 & $49.18-50.71$ \\
\hline 71 or more & 664 & 48.93 & 9.14 & $48.23-49.63$ \\
\hline \multicolumn{5}{|c|}{ Mental health (years) } \\
\hline $40-50$ & 824 & 49.64 & 9.55 & $48.99-50.30$ \\
\hline $51-60$ & 480 & 50.10 & 9.10 & $49.28-50.91$ \\
\hline $61-70$ & 452 & 49.34 & 9.67 & $48.45-50.23$ \\
\hline 71 or more & 664 & 50.16 & 8.80 & $49.49-50.83$ \\
\hline \multicolumn{5}{|c|}{ Role emotional (years) } \\
\hline $40-50$ & 822 & 48.78 & 6.80 & $48.32-49.25$ \\
\hline $51-60$ & 478 & 48.61 & 7.07 & $47.97-49.24$ \\
\hline $61-70$ & 449 & 47.00 & 8.00 & $46.26-47.74$ \\
\hline 71 or more & 656 & 47.47 & 8.22 & $46.84-48.10$ \\
\hline
\end{tabular}

SD: standard deviation; $95 \% \mathrm{Cl}: 95 \%$ confidence interval.

the quality of life of these populations, but suggest that future analyses regarding these regions should respectively focus on these aspects.

The only quality of life subscale that was not significantly influenced by an advance in age was mental health. This suggests that losses related to normal ageing may be more related to the physical component, which undergoes inexorable transformations over time 25. Compromised mental health, on the other hand, is more 
Mean values on subscales of the Short Form-8 according to schooling. Brazil, 2007.

\begin{tabular}{|c|c|c|c|c|}
\hline & $\mathrm{n}$ & Mean & SD & $95 \% \mathrm{Cl}$ \\
\hline \multicolumn{5}{|l|}{ General health } \\
\hline Illiterate/Incomplete Elementary & 1,103 & 41.94 & 7.59 & $41.49-42.39$ \\
\hline Complete Elementary/Incomplete Middle School & 601 & 43.81 & 7.92 & $43.17-44.44$ \\
\hline Complete Middle School/Incomplete High School & 295 & 44.97 & 8.05 & $44.05-45.89$ \\
\hline Complete High School/Incomplete University & 330 & 46.04 & 7.74 & $45.20-46.88$ \\
\hline Complete University or more & 91 & 48.53 & 7.79 & $46.91-50.15$ \\
\hline \multicolumn{5}{|l|}{ Physical functioning } \\
\hline Illiterate/Incomplete Elementary & 1,103 & 45.71 & 9.73 & $45.14-46.29$ \\
\hline Complete Elementary/Incomplete Middle School & 601 & 47.93 & 8.44 & $47.25-48.61$ \\
\hline Complete Middle School/Incomplete High School & 295 & 48.87 & 8.06 & $47.94-49.79$ \\
\hline Complete High School/Incomplete University & 330 & 49.73 & 7.46 & $48.92-50.54$ \\
\hline Complete University or more & 91 & 50.57 & 6.60 & $49.19-51.94$ \\
\hline \multicolumn{5}{|l|}{ Role physical } \\
\hline Illiterate/Incomplete Elementary & 1,103 & 44.80 & 10.18 & $44.20-45.40$ \\
\hline Complete Elementary/Incomplete Middle School & 601 & 47.76 & 8.89 & 47.05-48.47 \\
\hline Complete Middle School/Incomplete High School & 295 & 48.61 & 8.36 & $47.66-49.57$ \\
\hline Complete High School/Incomplete University & 330 & 49.72 & 7.67 & $48.89-50.55$ \\
\hline Complete University or more & 91 & 50.82 & 6.59 & $49.45-52.20$ \\
\hline \multicolumn{5}{|l|}{ Bodily pain } \\
\hline Illiterate/Incomplete Elementary & 1,103 & 46.96 & 11.47 & $46.28-47.64$ \\
\hline Complete Elementary/Incomplete Middle School & 601 & 49.18 & 11.19 & $48.29-50.08$ \\
\hline Complete Middle School/Incomplete High School & 295 & 50.39 & 10.73 & $49.16-51.62$ \\
\hline Complete High School/Incomplete University & 330 & 50.53 & 10.36 & $49.41-51.65$ \\
\hline Complete University or more & 91 & 53.10 & 10.05 & $51.00-55.19$ \\
\hline \multicolumn{5}{|l|}{ Vitality } \\
\hline Illiterate/Incomplete Elementary & 1,103 & 40.77 & 10.63 & $38.56-42.99$ \\
\hline Complete Elementary/Incomplete Middle School & 601 & 42.01 & 10.46 & $40.87-43.14$ \\
\hline Complete Middle School/Incomplete High School & 295 & 43.35 & 10.30 & $42.17-44.53$ \\
\hline Complete High School/Incomplete University & 330 & 43.79 & 10.16 & $42.98-44.61$ \\
\hline Complete University or more & 91 & 45.83 & 10.01 & $45.23-46.42$ \\
\hline \multicolumn{5}{|l|}{ Role social } \\
\hline Illiterate/Incomplete Elementary & 1,103 & 49.38 & 8.76 & $48.86-49.89$ \\
\hline Complete Elementary/Incomplete Middle School & 601 & 50.50 & 8.17 & $49.84-51.15$ \\
\hline Complete Middle School/Incomplete High School & 295 & 50.32 & 8.23 & 49.38-51.27 \\
\hline Complete High School/Incomplete University & 330 & 51.29 & 7.64 & $50.46-52.11$ \\
\hline Complete University or more & 91 & 52.12 & 6.88 & $50.69-53.56$ \\
\hline \multicolumn{5}{|l|}{ Mental health } \\
\hline Illiterate/Incomplete Elementary & 1,103 & 49.55 & 9.43 & $48.99-50.10$ \\
\hline Complete Elementary/Incomplete Middle School & 601 & 50.07 & 9.19 & $49.33-50.81$ \\
\hline Complete Middle School/Incomplete High School & 295 & 49.95 & 8.82 & $48.94-50.96$ \\
\hline Complete High School/Incomplete University & 330 & 49.71 & 9.47 & $48.69-50.74$ \\
\hline Complete University or more & 91 & 51.40 & 8.93 & $49.54-53.26$ \\
\hline \multicolumn{5}{|l|}{ Role emotional } \\
\hline Illiterate/Incomplete Elementary & 1,093 & 47.36 & 8.08 & $46.88-47.84$ \\
\hline Complete Elementary/Incomplete Middle School & 598 & 48.59 & 7.13 & $48.01-49.16$ \\
\hline Complete Middle School/Incomplete High School & 294 & 48.78 & 6.40 & $48.04-49.51$ \\
\hline Complete High School/Incomplete University & 329 & 48.27 & 7.52 & $47.46-49.09$ \\
\hline Complete University or more & 91 & 49.82 & 5.50 & $48.68-50.97$ \\
\hline
\end{tabular}

SD: standard deviation; 95\% Cl: 95\% confidence interval. 
Mean values on subscales and components of the Short Form-8 according to household income. Brazil, 2007.

\begin{tabular}{|c|c|c|c|c|}
\hline & $\mathrm{n}$ & Mean & SD & $95 \% \mathrm{Cl}$ \\
\hline \multicolumn{5}{|l|}{ General health } \\
\hline Up to $R \$ 300$ & 479 & 41.26 & 7.56 & $40.58-41.94$ \\
\hline $\mathrm{R} \$ 301$ to $\mathrm{R} \$ 500$ & 435 & 43.45 & 8.36 & $42.66-44.23$ \\
\hline $\mathrm{R} \$ 501$ to $\mathrm{R} \$ 1,000$ & 831 & 44.10 & 7.69 & $43.57-44.62$ \\
\hline $\mathrm{R} \$ 1,001$ to $\mathrm{R} \$ 1,800$ & 263 & 45.13 & 8.05 & $44.15-46.10$ \\
\hline $\mathrm{R} \$ 1,801$ or more & 145 & 46.28 & 7.89 & $44.98-47.57$ \\
\hline \multicolumn{5}{|l|}{ Physical functioning } \\
\hline Up to $\mathrm{R} \$ 300$ & 479 & 45.79 & 9.63 & $44.92-46.65$ \\
\hline $\mathrm{R} \$ 301$ to $\mathrm{R} \$ 500$ & 435 & 47.07 & 9.10 & $46.21-47.93$ \\
\hline $\mathrm{R} \$ 501$ to $\mathrm{R} \$ 1,000$ & 831 & 47.49 & 8.96 & $46.88-48.10$ \\
\hline $\mathrm{R} \$ 1,001$ to $\mathrm{R} \$ 1,800$ & 263 & 49.25 & 7.77 & $48.31-50.19$ \\
\hline $\mathrm{R} \$ 1,801$ or more & 145 & 50.42 & 6.40 & $49.37-51.47$ \\
\hline \multicolumn{5}{|l|}{ Role physical } \\
\hline Up to $R \$ 300$ & 479 & 45.22 & 9.84 & $44.34-46.11$ \\
\hline $\mathrm{R} \$ 301$ to $\mathrm{R} \$ 500$ & 435 & 46.43 & 9.72 & $45.52-47.35$ \\
\hline $\mathrm{R} \$ 501$ to $\mathrm{R} \$ 1,000$ & 831 & 47.08 & 9.32 & $46.44-47.71$ \\
\hline $\mathrm{R} \$ 1,001$ to $\mathrm{R} \$ 1,800$ & 263 & 48.98 & 8.34 & $47.97-50.00$ \\
\hline $\mathrm{R} \$ 1,801$ or more & 145 & 49.81 & 6.91 & $48.67-50.94$ \\
\hline \multicolumn{5}{|l|}{ Bodily pain } \\
\hline Up to $\mathrm{R} \$ 300$ & 479 & 46.80 & 11.80 & $45.75-47.86$ \\
\hline $\mathrm{R} \$ 301$ to $\mathrm{R} \$ 500$ & 435 & 48.30 & 11.19 & $47.24-49.35$ \\
\hline $\mathrm{R} \$ 501$ to $\mathrm{R} \$ 1,000$ & 831 & 48.81 & 10.95 & $48.06-49.55$ \\
\hline $\mathrm{R} \$ 1,001$ to $\mathrm{R} \$ 1,800$ & 263 & 49.87 & 10.85 & $48.55-51.18$ \\
\hline $\mathrm{R} \$ 1,801$ or more & 145 & 51.46 & 10.18 & $49.79-53.13$ \\
\hline \multicolumn{5}{|l|}{ Vitality } \\
\hline Up to $\mathrm{R} \$ 300$ & 479 & 40.84 & 9.49 & $39.28-42.40$ \\
\hline $\mathrm{R} \$ 301$ to $\mathrm{R} \$ 500$ & 435 & 41.96 & 9.78 & $40.77-43.14$ \\
\hline $\mathrm{R} \$ 501$ to $\mathrm{R} \$ 1,000$ & 831 & 44.25 & 10.21 & $43.56-44.95$ \\
\hline $\mathrm{R} \$ 1,001$ to $\mathrm{R} \$ 1,800$ & 263 & 44.36 & 10.53 & $43.37-45.36$ \\
\hline $\mathrm{R} \$ 1,801$ or more & 145 & 46.45 & 10.00 & $45.56-47.35$ \\
\hline \multicolumn{5}{|l|}{ Role social } \\
\hline Up to $R \$ 300$ & 479 & 48.25 & 9.29 & $47.42-49.09$ \\
\hline $\mathrm{R} \$ 301$ to $\mathrm{R} \$ 500$ & 435 & 50.28 & 8.23 & $49.51-51.06$ \\
\hline $\mathrm{R} \$ 501$ to $\mathrm{R} \$ 1,000$ & 831 & 50.58 & 7.89 & $50.04-51.11$ \\
\hline $\mathrm{R} \$ 1,001$ to $\mathrm{R} \$ 1,800$ & 263 & 51.59 & 7.54 & $50.67-52.50$ \\
\hline $\mathrm{R} \$ 1,801$ or more & 145 & 51.01 & 7.57 & $49.77-52.25$ \\
\hline \multicolumn{5}{|l|}{ Mental health } \\
\hline Up to $\mathrm{R} \$ 300$ & 479 & 48.65 & 9.61 & $47.78-49.51$ \\
\hline $\mathrm{R} \$ 301$ to $\mathrm{R} \$ 500$ & 435 & 49.98 & 8.77 & $49.15-50.80$ \\
\hline $\mathrm{R} \$ 501$ to $\mathrm{R} \$ 1,000$ & 831 & 50.22 & 9.18 & $49.59-50.84$ \\
\hline $\mathrm{R} \$ 1,001$ to $\mathrm{R} \$ 1,800$ & 263 & 50.59 & 8.98 & $49.50-51.69$ \\
\hline $\mathrm{R} \$ 1,801$ or more & 145 & 50.64 & 8.59 & $49.23-52.05$ \\
\hline \multicolumn{5}{|l|}{ Role emotional } \\
\hline Up to $R \$ 300$ & 474 & 46.63 & 8.37 & $45.87-47.38$ \\
\hline $\mathrm{R} \$ 301$ to $\mathrm{R} \$ 500$ & 434 & 48.00 & 7.39 & $47.30-48.69$ \\
\hline $\mathrm{R} \$ 501$ to $\mathrm{R} \$ 1,000$ & 825 & 48.48 & 7.21 & $47.99-48.97$ \\
\hline $\mathrm{R} \$ 1,001$ to $\mathrm{R} \$ 1,800$ & 262 & 49.04 & 6.47 & $48.26-49.83$ \\
\hline $\mathrm{R} \$ 1,801$ or more & 145 & 49.48 & 6.08 & $48.48-50.47$ \\
\hline
\end{tabular}

(continues) 


\begin{tabular}{lllll} 
Table 5 (continued) & $\mathbf{n}$ & Mean & SD & \\
\hline & & & & \\
\hline Physical component & 479 & 43.90 & 10.13 & $42.99-44.81$ \\
Up to $R \$ 300$ & 435 & 45.31 & 9.98 & $44.37-46.25$ \\
$\mathrm{R} \$ 301$ to $\mathrm{R} \$ 500$ & 831 & 45.99 & 9.76 & $45.33-46.66$ \\
$\mathrm{R} \$ 501$ to $\mathrm{R} \$ 1,000$ & 263 & 47.73 & 8.48 & $46.70-48.76$ \\
$\mathrm{R} \$ 1,001$ to $\mathrm{R} \$ 1,800$ & 145 & 49.15 & 7.39 & $47.94-50.37$ \\
$\mathrm{R} \$ 1,801$ or more & & & & \\
Mental component & 479 & 48.41 & 8.95 & $47.60-49.21$ \\
Up to $\mathrm{R} \$ 300$ & 435 & 49.51 & 7.98 & $48.76-50.26$ \\
$\mathrm{R} \$ 301$ to $\mathrm{R} \$ 500$ & 831 & 49.63 & 8.57 & $49.05-50.21$ \\
$\mathrm{R} \$ 501$ to $\mathrm{R} \$ 1,000$ & 263 & 49.15 & 7.97 & $48.18-50.12$ \\
$\mathrm{R} \$ 1,001$ to $\mathrm{R} \$ 1,800$ & 145 & 48.64 & 8.12 & $47.31-49.98$ \\
$\mathrm{R} \$ 1,801$ or more & & &
\end{tabular}

SD: standard deviation; $95 \% \mathrm{Cl}$ : $95 \%$ confidence interval.

related to health complications, which become more prevalent in old age, than with age per se, as demonstrated in previous studies carried out in Brazil 19,26,27,28.

The impact of schooling on health conditions has been widely studied and the association to socioeconomic status is well established $16,19,29$. In terms of quality of life, mental health was the only subscale that was not significantly influenced by this variable. Thus, compromised physical health appears to be more sensitive to socio-cultural adversities.

Household income had an influence over all the subscales in both the physical and mental components. The economic factor has been addressed in a number of studies that compare the expectation of a healthy life among populations in regions with different socioeconomic levels 16,29,30. The influence of income on health and wellbeing is well known and the data of the present study underscore the importance of this aspect in a large country with striking social disparity, such as Brazil. In this sense, studies conducted in Brazil showed that the higher the level of income and lower educational level, the worse the quality of life 19,20,21,22.

This study has limitations that should be addressed. No young individuals were included, as the study focused on the adult and elderly population based on the interest in studying the risk factors of osteoporosis within the scope of the BRAZOS Study. Since a multivariate analysis of the socio-demographic factors that affect quality of life among the Brazilian population was not performed, the results must be interpreted with caution, concerning the influence of socio-demographic factors on quality of life.
Although the SF-8 method was been developed in another culture, the use of this tool in our environment, facilitates the comparison of quality of life of the Brazilian population, with other international studies using the same measures. In addition, the norm-based score allow for an interpretation of population data as deviations of normality and they have the advantage of a direct interpretation in this regard, which facilitates decision-making. However, instruments for assessing quality of life have been developed specifically for the Brazilian population 31,32 , representing a major contribution to this field of research in our country and encouraging further studies that move in the same direction.

\section{Conclusions}

This study provides the mean values for the subscales and components of the SF-8, according to different socio-demographic factors, serving as the basis for comparisons with future clinical trials that use this measure for quality of life assessment in Brazil.

The Brazilian population has a lower degree of quality of life than the population of the United States of America, and the SF-8 values seemed to be influenced by gender, geographic region, family income, age and schooling. 


\section{Resumo}

Avaliar a qualidade de vida da população adulta brasileira, com base em normas populacionais norteamericanas. Estudo transversal de base populacional, por amostragem probabilística. Dois mil, quatrocentos e vinte indivíduos (725 homens e 1.695 mulheres) com idade de 40 anos ou mais foram avaliados em diferentes regiões geográficas brasileiras. Um questionário sociodemográfico e o SF-8 (Short Form-8) foram aplicados através de entrevista. Estatísticas descritivas, a análise de variância (ANOVA), o teste de MannWhitney e o teste de Tukey foram utilizados. O sexo feminino, a população da Região Nordeste e de Brasília (Distrito Federal), Goiânia (Goiás) e Campo Grande (Mato Grosso do Sul) apresentaram os piores níveis de qualidade de vida. A idade, a escolaridade e a renda familiar influenciaram negativamente vários domínios de qualidade de vida. O presente estudo apresenta estimativas de qualidade de vida, baseadas no SF-8, para a população adulta brasileira. As médias dos domínios e componentes sumários do SF-8 parecem sofrer influência do sexo, da região geográfica, da renda familiar, da idade e da escolaridade dos participantes.

Qualidade de Vida; Enquete Socioeconômica; Demografia; Nível de Saúde

\section{Contributors}

A. G. Campolina was responsible for the study design, statistical analysis and elaboration of the paper. M. M. Pinheiro, R. M. Ciconelli and M. B. Ferraz were responsible for the study design and paper elaboration.

\section{Acknowledgements}

This study was funded by a grant from Wyeth Consumer Healthcare, Brazil. The funding helped to implement the interviews in all the cities around Brazil and provided support for the statistical analysis.

\section{References}

1. Bowling A, Brazier J. Quality of life in social science and medicine. Soc Sci Med 1995; 41:1337-8.

2. Miettinen OS. Quality of life from the epidemiologic perspective. J Chronic Dis 1987; 40:641-3.

3. Spitzer WO. State of science 1986: quality of life and functional status as target variables for research. J Chronic Dis 1987; 40:465-71.

4. Ebrahim S. Clinical and public health perspectives and applications of health-related quality of life measurement. Soc Sci Med 1995; 41:1383-94.

5. Forattini OP. Qualidade de vida e meio urbano. A cidade de São Paulo, Brasil. Rev Saúde Pública 1991; 25:75-86.

6. Leplege A, Hunt S. The problem of quality of life in medicine. JAMA 1997; 278:47-50.

7. Coons SJ, Rao S, Keininger DL, Hays RD. A comparative review of generic quality-of-life instruments. Pharmacoeconomics 2000; 17:13-35.

8. Garratt AM, Ruta DA, Abdalla MI, Buckingham JK, Russell IT. The SF-36 health survey questionnaire: an outcome measure suitable for routine use within the NHS? BMJ 1993; 306:1440-4.
9. Ware JE, Kosinski M, Dewey JE, Gandek B. How to score and interpret single-item health status measures: a manual for users of the SF-8 Health Survey. Lincoln: Quality Metric Inc.; 2001.

10. Ware JE, Snow KK, Kosinski M, Gandek B. SF-36 Health Survey manual and interpretation guide. Boston: The Health Institute, New England Medical Center; 1993.

11. Ciconelli RM, Ferraz MB, Santos W, Meinão I, Quaresma MR. Tradução para a língua portuguesa e validação do questionário genérico de avaliação de qualidade de vida SF-36 (Brasil SF-36). Rev Bras Reumatol 1999; 39:143-50.

12. Cunha ACV, Burke TN, França FJR, Marques AP. Effect of global posture reeducation and of static stretching on pain, range of motion, and quality of life in women with chronic neck pain: a randomized clinical trial. Clinics 2008; 63:763-70.

13. Lopes C, Esteves AM, Bittencourt LRA, Tufik S, Mello MT. Relationship between the quality of life and the severity of obstructive sleep apnea syndrome. Braz J Med Biol Res 2008; 41:908-13. 
14. Santos FR, Filgueiras MST, Chaoubah A, Bastos MG, Paula RB. Efeitos da abordagem interdisciplinar na qualidade de vida e em parâmetros laboratoriais de pacientes com doença renal crônica. Rev Psiquiatr Clin (São Paulo) 2008; 35:87-95.

15. Pinheiro MM, Ciconelli RM, Martini LA, Ferraz MB. Risk factor for recurrent falls among Brazilian women and men: the Brazilian Osteoporosis Study (BRAZOS). Cad Saúde Pública 2010; 26:89-96.

16. Gutiérrez-Fisac JL, Gispert R, Sola J. Factors explaining the geographical differences in disability free life expectancy in Spain. J Epidemiol Community Health 2000; 54:451-5.

17. Mathews RJ, Jagger C, Hancock RM. Does socioeconomic advantage lead to a longer, healthier old age? Soc Sci Med 2006; 62:2489-99.

18. Marra CA, Lynd LD, Esdaile JM, Kopec J, Anis AH. The impact of low family income on self-reported health outcomes in patients with rheumatoid arthritis within a publicly funded health-care environment. Rheumatology 2004; 43:1390-7.

19. Alves LC, Rodrigues RN. Determinantes da autopercepção de saúde entre idosos do Município de São Paulo, Brasil. Rev Panam Salud Pública 2005; 17:333-41.

20. Lima MG, Barros MBA, César CLG, Goldbaum M, Carandina L, Ciconelli RM. Health related quality of life among the elderly: a population-based study using SF-36 survey. Cad Saúde Pública 2009; 25:2159-67.

21. Feliciano AB, Moraes SA, Freitas ICM. O perfil do idoso de baixa renda no Município de São Carlos, São Paulo, Brasil: um estudo epidemiológico. Cad Saúde Pública 2004; 20:1575-85.

22. Lorenzi DRS, Baracat EC, Saciloto B, Padilha Jr. I. Fatores associados à qualidade de vida após menopausa. Rev Assoc Med Bras (1992) 2006; 52:312-7.

23. Camargos MCS, Perpetuo IHO, Machado CJ. Expectativa de vida com incapacidade funcional em idosos em São Paulo, Brasil. Rev Panam Salud Pública 2005; 17:379-86.
24. Ellert U, Lampert T, Ravens-Sieberer U. Measuring health-related quality of life with the SF-8. Normal sample of the German Population. Bundesgesundheitsblatt Gesundheitsforschung Gesundheitsschutz 2005; 48:1330-7.

25. Kaarlola A, Tallgren M, Pettilä V. Long-term survival, quality of life, and quality-ajusted life years among critically ill elderly patients. Crit Care Med 2006; 34:2120-6.

26. Alves LC, Benício MHD’A, Alves MCGP, Lebrão ML. A influência das doenças crônicas na capacidade funcional dos idosos do Município de São Paulo, Brasil. Cad Saúde Pública 2007; 23:1924-30.

27. Duarte YA, Lebrão ML, Lima FD. Contribuição dos arranjos domiciliares para o suprimento de demandas assistenciais dos idosos com comprometimento funcional em São Paulo, Brasil. Rev Panam Salud Pública 2005; 17:370-8.

28. Rosa TEC, Benício MHA, Alves MCGP, Lebrão ML. Aspectos estruturais e funcionais do apoio social de idosos do Município de São Paulo, Brasil. Cad Saúde Pública 2007; 23:2982-92.

29 Brønnum-Hansen H, Davidsen M. Social differences in the burden of long-standing illness in Denmark. Soz Praventivmed 2006; 51:221-31.

30. Davis P, Graham P, Pearce N. Health expectancy in New Zealand, 1981-1991: social variation and trends in a period of rapid social and economic change. J Epidemiol Community Health 1999; 53:519-27.

31. Lima MJB, Portela MC. Elaboração e avaliação da confiabilidade de um instrumento para a medição da qualidade de vida relacionada à saúde de idosos independentes. Cad Saúde Pública 2010; 26:1651-62.

32. Paschoal SMP, Jacob Filho W, Litvoc J. Development of Elderly Quality of Life Index - EqoLi: item reduction and distribution into dimensions. Clinics 2008; 63:179-88.

Submitted on 19/Oct/2010

Final version resubmitted on 17/Mar/2011

Approved on 29/Mar/2011 